\title{
ЛІНГВОДИДАКТИЧНІ ЗАСАДИ НАВЧАННЯ МОРФОЛОГІЇ В ЗАГАЛЬНООСВІТНІЙ ШКОЛІ
}

Цоуфал Л. С. Лінгводидактичні засади навчання морфології в загальноосвітній школі.

У статті висвітлено лінгводидактичні засади навчання морфології в загальноосвітній школі, охарактеризовано специфічні принципи засвоєння навчального матеріалу з морфології, окреслено шляхи реалізації сучасних підходів у навчанні української мови.

Ключові слова: закономірності навчання української мови, принципи навчання української мови, специфічні принципи, специфічні прийоми навчання морфології.

Цоуфал Л.С. Лингводидактические основы обучения морфологии в общеобразовательной школе.

В статье раскрыты лингводидактические основы обучения морфологии в общеобразовательной школе, охарактеризованы специфические принципы усвоения 
учебного материала по морфологии, намечены пути реализации современных подходов в обучении украинского языка.

Ключевые слова: закономерности обучения украинскому языку, принципы обучения украинскому языку, специфические принципы, специфические прийомы обучения морфологии.

Tsoufal L. S. Linguistic and didactical basics of teaching morphology in school.

The article deals with linguistic and didactical basics of teaching morphology in school. The author describes specific principles of learning the material in morphology and depicts the ways of realization of modern approaches in teaching the Ukrainian language.

Key words: regularities in teaching the Ukrainian language, principles of teaching the Ukrainian language, specific principles, specific processes in teaching the morphology.

В умовах сучасної школи основна мета вивчення української мови полягає у формуванні національно свідомої, духовно багатої мовної особистості, яка володіє вміннями і навичками вільно послуговуватися засобами рідної мови в усіх видах мовленнєвої діяльності. Незаперечною є думка лінгводидактів, що рівень оволодіння мовою визначається значною мірою рівнем опанування їі граматичною системою.

У чинних програмах з рідної мови вивчення граматики посідає чільне місце, оскільки учні повинні не лише засвоїти будову української мови, а й оволодіти навичками практичного іiі використання. Вивчення граматичних законів і правил забезпечує вільне та правильне висловлювання своїх думок, сприймання й розуміння чужих, сприяє формуванню умінь i навичок свідомого й доречного використання засобів мови в комунікативній ситуації.

Місце й значення морфології у шкільному курсі української мови визначається значенням слова в мові: зрозуміти структуру й функції мови, оволодіти мовними засобами неможливо без усвідомлення тих властивостей слів, що зумовлюють їхню сполучуваність. Вирішальну роль у цьому, поряд із лексичним значенням слів, відіграє їх здатність змінюватися, виступати в певних граматичних формах, кожна 3 яких вирізняється додатковими смисловими відтінками або виражає певні відношення між елементами думки. Ознайомлення з формами словозміни сприяє оволодінню нормами української літературної мови, розвитку логічного мислення і зв'язного мовлення учнів.

Методика навчання граматики вже набула відповідного досвіду. Вагомий внесок у розроблення теоретичних основ навчання морфології зробили О. Біляєв, М. Вашуленко, В. Горяний, Н. Грипас, С. Караман, В. Масальський, В. Мельничайко, І. Олійник, М. Пентилюк, М. Плющ, Л. Симоненкова, С. Чавдаров, М. Шкільник

Мета нашої статті полягає у висвітленні лінгводидактичних засад навчання морфології в загальноосвітній школі.

Аналіз науково-методичної літератури, сучасних концепцій навчання української мови, чинних програм засвідчує, що під час вивчення 
морфології реалізуються такі основні завдання, як-от: виробити чітке уявлення про систему морфологічних груп слів, про синтаксичну функцію слів у словосполученні і реченні; ознайомити учнів зі складом частин мови, із поділом їх на самостійні і службові, із виділенням в особливу частину мови вигуків; забезпечити усвідомлення учнями форм словозміни, якою характеризуються частини мови, навчити правильно використовувати ці форми для побудови словосполучень i речень; ознайомити зі словотворенням частин мови. У процесі навчання морфології необхідно сформувати в учнів передусім такі уміння й навички: розпізнавати частини мови, визначати їх постійні й непостійні ознаки, синтаксичну роль, правильно утворювати частини мови відповідно до відомих способів словотвору, стилістично доцільно використовувати в мовленні слова різних частин мови.

Об'єктом вивчення морфології, як відомо, є слово як носій ряду граматичних значень, властивих певній частині мови. Відповідно до вияву граматичних значень слово зазнає формальної видозміни, утворюючи усталену мовною практикою систему словоформ. Видозміни слова, що служать для вираження його синтаксичних властивостей (відношень між словами), називають словозміною. А система словоформ, співвідносних 3 певною системою синтаксичних граматичних значень, називається його парадигмою [4, с. 9].

Слово $є$ основною одиницею двох рівнів - лексичного і граматичного. Хоч граматичні значення слова не тільки не ізольовані від лексичного, але й тісно взаємодіють із ним, граматика абстрагується від лексичних значень і оперує поняттям слова як граматичної одиниці мови. В. Адмоні зазначає: «Особливе місце 3-поміж одиниць граматичної будови посідає слово своєю причетністю до різних сфер мови. Зокрема, усередині граматичної системи воно утворює, $з$ одного боку, неподільну єдність 3 морфемою, оскільки обидві ці одиниці у своєму існуванні з необхідністю передбачають одна одну і в своїй взаємодії складають окрему сферу граматичної будови морфологічну. 3 другого боку, воно тісно пов'язане 3 реченням i словосполученням, складаючи у своїй взаємодії 3 ним іншу сферу граматичної будови - синтаксичну» [1, с. 8$]$.

Вивчення шкільного курсу морфології починається зі з'ясування питань про поділ слів на частини мови. У мовознавстві наявні протилежні погляди щодо кількості та якості критеріїв зарахування слів до певних частин мови: класифікація мовних одиниць за одним критерієм (гомогенна) i класифікація за кількома різнорідними критеріями (гетерогенна). Гомогенна класифікація має свої внутрішні відмінності, адже в ролі єдиного критерію використовуються різні ознаки: чи то лексична (семантична), чи то морфологічна, чи то синтаксична. Використання будьякого єдиного критерію не забезпечило несуперечливої класифікації частин мови. Виокремлення частин мови за набором різнорідних ознак не 
сприяло створенню єдиної класифікації частин мови, оскільки мовознавці по-різному визначають класифікаційні ознаки, надають перевагу одній із них. Питання про розподіл слів на певні лексико-граматичні класи досі залишається остаточно не 3'ясованим лінгвістичною наукою, існують різні позиції навіть щодо кількості частин мови. У традиційній граматиці класифікація здійснюється 3 урахуванням спільних лексичних ознак, граматичних категорій, синтаксичних функцій та засобів словотвору.

Шкільна практика здебільшого грунтується на позиції, що в українській мові - десять частин мови. Шість із них (іменник, прикметник, числівник, займенник, дієслово, прислівник) самостійні, три (прийменник, сполучник, частка) службові та вигук. Змінюваними є п'ять частин мови: іменник, прикметник, числівник, займенник i дієслово, усі інші незмінювані. Самостійні частини мови можуть виступати членами речення, слова, що належать до них, називаються повнозначними. Службові частини мови членами речення не виступають, вони виконують допоміжну роль у творенні членів речення. Ці слова називаються неповнозначними.

Деякі мовознавці як окремі частини мови виділяють слова категорії стану, модальні слова, зв'язки. 3 цими «нетрадиційними» частинами мови учні знайомляться при вивченні прислівників, безособових речень, вставних слів, але без використання відповідних термінів.

Уважаємо необхідним зазначити, що критерії виокремлення частин мови як теоретичне питання у школі не розглядаються, однак у практичній роботі вони знаходять широке застосування: учні повинні навчитися розрізняти частини мови, диференціювати кожне конкретне слово за частиномовною належністю.

Відомості, що подаються у школі, повинні становити певну систему понять і фактів, які дають уявлення про саму мову й науку про неї, а також сприяти практичному оволодінню мовою. У методичних працях О. Біляєва, О. Текучова, М. Шкільника зазначається, що шкільна граматика повинна являти собою популярно викладену наукову граматику. Різниця між шкільною і науковою граматикою повинна полягати не у змісті, а в обсязі матеріалу, у відборі для школи найбільш важливого і необхідного, а також у способах його подачі учням і сфері використання.

Ефективність навчання морфології залежить не тільки від опанування учнями мовних понять і правил, а й від організації роботи, від вдалого добору дидактичного матеріалу. Методичні засоби навчання мають бути лінгвістично обгрунтованими, відповідати характеру й змісту виучуваного матеріалу. Добираючи приклади, необхідно враховувати всі особливості мовних одиниць, варіювати найсуттєвіші їхні ознаки для забезпечення усвідомлення найважливіших визначальних понять.

Граматичні поняття формуються внаслідок тривалої роботи над відповідним мовним матеріалом, запропонованим учителем. Ця робота 
складається 3 таких компонентів, як сприймання окремих однорідних мовних явищ, абстрагування, визначення істотних для відповідної групи явищ ознак, узагальнення їх у спеціальному слові-терміні. Ученимиметодистами (М. Вашуленко, С. Дорошенко) визначено чотири етапи процесу формування граматичних понять. Перший етап передбачає аналіз мовного матеріалу задля виокремлення істотних ознак поняття. Виконанням таких операцій, як аналіз і синтез, учні абстрагуються від лексичного значення слів і виділяють граматичні ознаки, типові для даного мовного явища. Другий етап формування граматичних понять полягає в узагальненні істотних ознак, установленні зв'язків між ними та в уведенні терміна, засвоєння якого полегшує оперування граматичним поняттям. Своєчасне ознайомлення учнів 3 терміном сприяє швидкому виокремленню, уточненню та глибокому засвоєнню поняття. Третій етап пов'язується 3 уточненням суті ознак поняття i зв'язків між ними. Четвертий етап формування граматичного поняття полягає в конкретизації поняття завдяки виконанню вправ, які вимагають практичного застосування одержаних знань.

Л. Скуратівський зауважує: на початку вивчення морфології необхідно, аби учні вивели і сформулювали основні ознаки поняття «частина мови»: загальне значення, граматичні ознаки, синтаксичну роль, що дасть змогу використовувати їх як план дослідження більш конкретних понять - іменника, прикметника та інших самостійних частин мови. Тобто кожна частина мови вивчатиметься не як абсолютно нове поняття, а розглядатиметься як частковий вияв більш загального. Тим самим будуть забезпечуватися системність, міцність знань школярів [6, с. 88].

Сучасні лінгводидакти вважають, що навчання української мови спирається на об'єктивні, постійні взаємозв'язки між предметами, явищами, процесами - закономірності, урахування яких сприяє ефективній організації навчального процесу. До закономірностей навчання і засвоєння рідної мови науковці зараховують:

- постійну увагу до матерії мови, її звукової системи;

- розуміння семантики мовних одиниць;

- здатність засвоювати норми літературної мови;

- оцінку виражальних можливостей рідної мови;

- розвиток мовного чуття, дару слова;

- випереджувальний розвиток усного мовлення;

- залежність мовленнєвих умінь і навичок від знань граматики i словникового складу мови [2, с. 30-31]. Урахування таких закономірностей навчання допоможе вчителю реалізувати зміст навчання морфології в загальноосвітній школі, розробити ефективну методику формування мовної особистості.

Навчання української мови здійснюється на основі дидактичних принципів, які забезпечують належний рівень засвоєння змісту шкільного 
курсу мови i формування комунікативних умінь i навичок. Принципи навчання мови - це своєрідні правила навчальної діяльності вчителя, шляхи взаємодії вчителя i учнів, це вихідні положення, на яких грунтується зміст навчання, використання методів і прийомів, побудови системи вправ, підготовки i проведення уроків української мови. Дослідники розрізняють загальнодидактичні i специфічні принципи навчання. 3-поміж традиційних загальнодидактичних принципів виокремлюють науковість, систематичність і послідовність, наступність і перспективність, зв'язок теорії з практикою, наочність, свідомість, доступність викладу. До сучасних загальнодидактичних принципів зараховують гуманізацію, гуманітаризацію, співтворчість і співробітництво, розвивальний характер навчання, індивідуалізацію, диференціацію, оптимізацію і т. ін. К. Плиско, визначаючи лінгводидактичні основи навчання української мови на сучасному етапі розвитку освіти, підкреслює, що система принципів навчання мови поповнилася такими, як-от: комунікативно-діяльнісний, проблемно-пошуковий, культурологічний та ін. «Знання принципів навчання та їхніх вимог до організації навчання мови дає змогу правильно визначити мету, зміст, методи, засоби і форми навчання, тобто кваліфіковано організувати навчально-виховний процес; до того ж 3 гарантованим результатом навчання [3, с. 34].

Методика вивчення частин мови грунтується на специфічних принципах, що усталилися в сучасній лінгводидактиці:

- вивчення частин мови у зв'язку з фонетикою, лексикою та іншими розділами;

- вивчення частин мови на синтаксичній основі;

- вивчення системи відмінювання частин мови і словотвору у зв'язку з орфографією;

- вивчення частин мови в поєднанні з розвитком мовлення [5, с. 146].

У процесі опрацювання морфології відомості з фонетики і графіки сприяють усвідомленню формальних ознак частин мови, поділу іменників та прикметників на групи, розрізненню подібних граматичних форм тощо. Зв’язок морфології з лексикою дозволяє розглядати слово в єдності змісту і форми, розмежовувати лексико-граматичні значення, властиві частинам мови, і лексичне значення кожного слова в межах однієї частини мови й одного речення. Наявність паралельних морфологічних форм дозволяє вести стилістичні спостереження над способами досягнення милозвучності вислову, над функціонально-стилістичною диференціацією мовних засобів.

Поділяємо думку методистів, що вивчення морфології необхідно органічно поєднувати 3 вивченням орфографічних правил, які часто стосуються певної частини мови або конкретних форм. Наприклад, написання складних прикметників, написання прислівників, буква в у дієсловах наказового способу. Опрацювання форм словозміни та спостереження над способами творення слів необхідно спрямувати не 
лише на збагачення словника учнів, вироблення вміння послуговуватися формами в мовленні, а й на вивчення відповідних орфограм, скажімо,

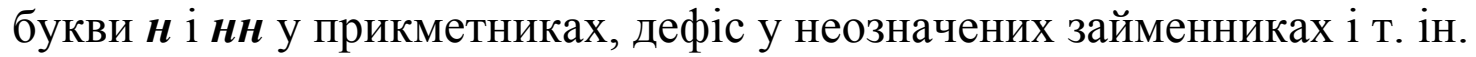

У роботах багатьох лінгводидактів стверджується думка про необхідність вивчення морфології на синтаксичній основі. Слушними $€$ міркування В. Мельничайка, М. Пентилюк, М. Плющ, Т. Донченко, які зазначають, що особливості слова пов'язані 3 його синтаксичними властивостями, тому в курсі морфології необхідно враховувати ці особливості в межах кожної частини мови із застосуванням синтаксичних понять і термінів, що відображають їхні зв'язки з іншими словами.

Опрацювання морфології на синтаксичній основі науковці пропонують здійснювати задля:

а) диференціації певних морфологічних одиниць - спільнокореневих слів, що належать до різних частин мови (n'ять, n'ятірка; оголосити, оголочення) або різних граматичних форм (червоніючі яблука - червоніючи від сорому), омоформ одного слова (матері) чи різних слів (збудую буду, буду піклуватися), однозвучних слів та сполучень слів (догори - до гори);

б) установлення граматичних ознак незмінюваних слів;

в) формування уявлення про певний розряд слів, наприклад, про відносні займенники що служать для зв'язку частин складного речення, чи прийменники, які є засобом структурного оформлення словосполучень;

г) запобігання ряду помилок (зробити по-новому, по новому шосе);

д) пропедевтичного ознайомлення з синтаксичними конструкціями, обов'язковими компонентами яких є морфологічні форми в своїй типовій функції (дієслівні форми на -но, -то у ролі головного члена безособового речення), форма кличного відмінка іменника в ролі звертання;

е) ознайомлення 3 такими поняттями, як дієприкметниковий та дієприслівниковий звороти, їх пунктуаційним оформленням.

На думку М. Пентилюк, опрацювання морфології на синтаксичній основі забезпечує виконання ще таких важливих завдань, як-от: ознайомлення учнів зі стилістичним використанням морфологічних одиниць; формування умінь і навичок зв'язного мовлення.

Провідними підходами на сучасному етапі шкільної освіти $\epsilon$ передусім такі: комунікативно-діяльнісний, функціонально-стилістичний, соціокультурний, компетентнісний. Їхнє впровадження можливе за умови навчання мови на текстовій основі. Саме текст дає змогу репрезентувати різноманітні ознаки мови як системи, забезпечує більш ефективне засвоєння мовних явищ, уможливлює усвідомлення будь-яких відтінків лексичних i граматичних значень слів, словоформ, конструкцій, стилістичних особливостей використання.

Лінгвістичного обгрунтування вимагає вибір методичних засобів навчання - методів опрацювання навчального матеріалу, способу організації навчальної роботи. При цьому необхідно враховувати три 
основні чинники: 1) характер навчального матеріалу 3 морфології; 2) рівень мовного розвитку школярів; 3) особливості мовного середовища, його розвивальний потенціал.

Уважаємо, що теоретичний матеріал 3 морфології можна опрацьовувати різними способами, перевіреними практикою навчання - за допомогою розповіді вчителя, спостереження над мовою, пошукової бесіди, проблемним викладом матеріалу, самостійного опрацювання теми за підручником і т. ін.

Лінгвістичний аспект визначає i вибір специфічних прийомів навчання. Найбільш ефективними, на нашу думку, є: морфологічний розбір (повний або частковий, усний або письмовий), розмежування аналогічних слів, постановка слова в потрібній формі; що належать до різних частин мови; зіставлення граматичних форм; заміна одних форм іншими; спостереження над функціонуванням паралельних морфологічних форм; складання словосполучень і речень 3 певними формами слів; алгоритмізація і т. ін.

Вдумливого підходу потребує застосування на уроках мовних ілюстрацій, дидактичного матеріалу вправ. Крім вимог до змісту, він повинен задовольняти і вимоги суто лінгвістичні. Добираючи вправи, треба дбати, щоб їх виконання допомагало практично осмислити теоретичний матеріал, зробити його надбанням мовного досвіду кожного учня, забезпечувало формування практичних умінь і навичок. Системні знання про лінгвістичну природу частин мови, функціональну роль у мовленні сприятимуть мовленнєвому розвитку школярів, формуванню мовної і мовленнєвої компетенції учнів.

\section{Література}

1. Адмони В. Г. Основы теории граматики / В. Г. Адмони. - М. ; Л. : Наука, 1964. - 105 с. 2. Методика навчання української мови в середніх освітніх закладах / [М. І. Пентилюк, С. О. Караман, О. В. Караман та ін.]; за ред. М. І. Пентилюк. - К. : Ленвіт, 2005. - 400 с.

3. Плиско К. М. Лінгводидактичні основи навчання української мови в середніх закладах освіти / К. М. Плиско // Педагогічні науки : [зб. наук. праць]. Херсон : Видавництво ХДПУ, 2002. - Вип. 31. - С.34-37.

4. Плющ М. Я. Вивчення морфології в 5-6 класах : [посібник для вчителя] / М. Я. Плющ. - К. : Радянська школа, 1988. - 168 с.

5. Практикум з методики навчання української мови / [M. І. Пентилюк, С. О. Караман, О. В. Караман та ін.]; за ред. М. І. Пентилюк. - К. : Ленвіт, 2003. $-302 \mathrm{c}$.

6. Скуратівський Л. В. Пізнавальні завдання з української мови : [посібник для вчителя] / Л. В. Скуратівський. - К. : Радянська школа, 1987. - 144 с. 